\title{
The Effect of Exogenous HSP70 on Expression Kinetics of HSP70, HSP90, HSP110 and IL2 and IL6 in Peripheral Blood Mononuclear Cells and Possible Crosstalk between Them in Black Bengal Goat
}

\author{
Tanmay Mondal ${ }^{1}$, Chandrabhan Singh Banjare ${ }^{1}$, Satyaveer Singh Dangi ${ }^{1}$, Sadhan Bag ${ }^{1}$, \\ Mihir Sarkar ${ }^{1}$ and Bikash Chandra Das ${ }^{2 *}$ \\ ${ }^{1}$ Physiology \& Climatology, Indian Veterinary Research Institute, Izatnagar, \\ Bareilly-243122, Uttar Pradesh, India \\ ${ }^{2}$ Eastern Regional Station, Indian Veterinary Research Institute, 37 Belgachia Road, \\ Kolkata-700037, India \\ *Corresponding author
}

\begin{abstract}
A B S T R A C T
The present study was aimed to investigate the modulatory effect of eHSP70 on major heat stressed genes in in-vitro cell culture system. HSP70 (eHSP70) on mRNA expression

Keywords

Goat, Kinetics, Heat stress, HSP, IL, PBMC

Article Info

Accepted:

06 July 2018

Available Online:

10 August 2018 profile of Heat shock protein 70 (HSP70), Heat shock protein 90 (HSP90), Heat shock protein 110 (HSP110), Interleukin-2 (IL-2), Interleukin-6 (IL-6) in peripheral blood mononuclear cells (PBMC) in cell culture model of black Bengal Goat. The cultured PBMCs were treated with a specific dose of eHSP70 $(50 \mathrm{ng} / \mathrm{ml})$ at $37^{\circ} \mathrm{C}$ for $0,1,2,4,8$, $12,16,20,24$ hours. The mRNA expression of the above mentioned genes were determined by quantitative real-time PCR (qRT-PCR). The proteins were immunochemically localized by the cultured PBMCs. The study showed that on administration of eHSP70 to the PBMCs cell culture system, the relative mRNA expression of iHSP70, HSP90 and HSP110 increased significantly $(\mathrm{p}<0.05)$ at 4, 20 and 24 h compared with control and Interleukins (IL-2), (IL-6), showed significantly higher expression $(\mathrm{p}<0.05)$ at 4 and $24 \mathrm{~h}$ compared with control. Immunoreactivity revealed that all genes under study were localized in cytoplasm as well as in nucleus. The differential expression pattern of above mentioned genes at specific dose of eHSP70 might indicate their role in maintaining the cellular homeostasis during heat stress.
\end{abstract}

\section{Introduction}

Heat is a naturally occurring factor of environment and show deleterious effect on animals and causes serious consequences. Higher temperature above $42^{\circ} \mathrm{C}$ is generally considered to be life threatening (Bettaieb and Averill-Bates, 2008). Heat shock proteins
(HSP) are molecular chaperones. They protect cells from extreme physiological, pathological, and environmental conditions (Kiang, 2004). In an unstressed cell the constitutively expressed HSP regulate protein folding, protein translocation across membranes, assembly, and disassembly of protein oligomers, degradation of aged 
proteins, etc. Inducible HSP can correct protein misfolding and preserve immature polypeptides from aggregation under stresses. Nevertheless 210 genes were up regulated and 250 genes were down regulated by the heat stress (Kolli et al., 2014). In the presence of HSP70 in extracellular compartment, it has been shown to facilitate innate immunity (Aneja et al., 2006). eHSP70 has vital role in pro-inflammatory immune response (Pockley, 2003); therefore, changes in eHSP70 may be an indication of cellular damage within the intestines (Doklandy et al., 2006).

Black Bengal Goat is the most common indigenous breed of Goat, mostly found in the Eastern and North-Eastern region of India and famous worldwide mainly for its high quality chevon and skin. In India, Goats are kept free for grazing most of the daytime. So, there is always a great chance to encounter with heat stress. To obtain optimum productivity from Black Bengal Goats, an insight into the heat stress induced genes expression would provide a key to other basic researches on stress amelioration.

Cytokines are soluble signals of paramount importance mediating cell-to-cell communication during inflammatory and immune responses. Among the cytokines, IL-6 was found to be produced by cells at local tissue sites and the circulating IL-6 plays an important role in the induction of acute phase reactions by acting upon the liver and the hypothalamic-pituitary-adrenal axis (Ruzek et al., 1997).

IL-6 can even modulate thermal stress in some animal tissues (Parikh et al., 1998; Yildirim and Yurekli, 2010). The lymphokine IL-2, released by stimulated T-cells, is required for lymphocyte proliferation and it has been demonstrated that stressors may cause decreased IL-2 production in calves (Blechaand Baker, 1986). The higher expression of IL-2 and IL-6 during summer is also in accordance with the previous study of (Hershko et al., 2003) that induction of the heat shock response increased IL-6 production in gut mucosa in vivo and in cultured Caco-2 cells in vitro. Recent studies showed that acute heat stress promoted the production of IL-2 by lymphocytes due to increased lymphocyte proliferation in broiler (Han et al., 2010). The HSP act cognitively in cellular and tissue homeostasis (DeJong et al., 2009) and are released intra-cellularly and extra-cellularly in an inducible form in response to stress (Hecker and McGarvey, 2011). The higher expression of interleukin genes may have some cell protective role in thermal stress. To the best of our knowledge, no study has so far given an in-depth insight into the analysis of exogenous effect of HSP70 variation on the relative expression of major heat stress genes in PBMCs of Black Bengal breed of Goats. Hence, the present in vitro study was planned to assess the exogenous effect of HSP70on expression kinetics of HSP70, HSP90, HSP110, IL2, IL6, in PBMCs of the black Bengal Goat.

\section{Materials and Methods}

\section{Animals and blood collection}

Six female Black Bengal Goat (2-3 years old) apparently healthy with average body weight of 20-24 kg were selected from the experimental herd of the Division of Physiology and Climatology, Indian Veterinary Research Institute (IVRI), Izatnagar, India. Animals were maintained under semi intensive housing conditions with access to ad lib water and feeds. Blood samples $(10 \mathrm{ml})$ were collected from animals by jugular vein puncture in heparinized vacutainer under aseptic conditions and were transported to the laboratory in cold chain. The blood samples were collected at mean temperature humidity index of $66.97 \pm 1.01$. 


\section{Separation of PBMCs}

PBMCs were isolated by density gradient centrifugation method using Histopaque 1077 (Sigma, USA) as per manufacturer's instructions. The cells were washed thrice in Dulbecco's phosphate buffer saline (DPBS; $\mathrm{pH}$ : 7.4) by centrifugation at $425 \times \mathrm{g}$ for $5 \mathrm{~min}$ at $25^{\circ} \mathrm{C}$. Cells were counted using hemocytometer and viability was determined by the trypan blue exclusion method (Tolnai, 1975). Cells viability was typically greater than $90 \%$.

\section{Heat challenge treatment of PBMCs}

The PBMCs were then re suspended at a concentration of $2 \times 10^{6}$ live cells $/ \mathrm{ml}$ in RPMI1640 (Cat no.- 1260454, Lot no.- MR29830, MP biological, France) medium containing $10 \%$ fetal bovine serum (FBS), $100 \mathrm{IU} / \mathrm{ml}$ penicillin, $100 \mu \mathrm{g} / \mathrm{ml}$ streptomycin. The cells were then plated out at $2 \times 10^{6}$ viable cells per well in $4 \times 612$-well plate and incubated in a humidified $\mathrm{CO}_{2}(5 \%)$ incubator at $37^{\circ} \mathrm{C}$ over a period of 24 hours at different time interval i.e $(0,1,2,4,8,12,16,20,24 \mathrm{hr})$. After the incubation of specific time interval total RNA was extracted from PBMCs and the incubated culture plate at $37^{\circ} \mathrm{C}$ was used for immunocytochemistry.

\section{Primers}

The primers of HSP70, HSP90, HSP105/110, Ribosomal protein S15a (RPS15A) and beta actin (Dangi et al., 2014), IL2, IL6, were taken from published sequence. The sequences, efficiency, and expected PCR Product length are presented in Table 1.

Total RNA extraction and quality determination

Total RNA was isolated from PBMCs using One Step RNA reagent (Bio Basic Inc.,
Canada) following manufacturer recommendations. To remove any contamination by genomic DNA, the samples were submitted to digestion with DNase 1 (D5025; Sigma). The extracted RNA was quantified by using spectrophotometer and the $\mathrm{OD}_{260} / \mathrm{OD}_{280}$ was used for evaluation of quality. The integrity of the RNA was checked by visualization of $18 \mathrm{~s}$ and $28 \mathrm{~s}$ ribosomal bands on $1 \%$ agarose gel.

\section{Quantitative RT-PCR analysis}

Quantitative real-time PCR was performed using Ssofast Eva Green ${ }^{\circledR}$ qPCR kit, Biorad, USA. Each sample was run in triplicate in 20 $\mu \mathrm{l}$ reaction mixture which was consisted of 10 $\mu \mathrm{l}$ Eva green mix, $0.5 \mu \mathrm{l}$ each of forward $(0.25$ $\mu \mathrm{M})$ and reverse primer $(0.25 \mu \mathrm{M}), 1 \mu \mathrm{l}$ of cDNA and $8 \mu \mathrm{l}$ nuclease-free water. The realtime PCR (MxPro3005P Stratagene, Agilent Technologies, USA) was run with initial denaturation at $95^{\circ} \mathrm{C}$ for $30 \mathrm{sec}$ followed by 40 cycles of denaturation at $95^{\circ} \mathrm{C}$ for $5 \mathrm{sec}$, annealing for $10-12 \mathrm{sec}$ and extension at $72^{\circ} \mathrm{C}$ for $10 \mathrm{sec}$. The optimum annealing temperatures for different genes are presented in Table 1.

Real time PCR efficiencies were determined by amplification of a standardized dilution series, and slopes were obtained. To assess the specificity of amplified product, dissociation curve for each gene was generated at temperature of $65-95^{\circ} \mathrm{C}$. Results were expressed as changes in threshold cycle values (CT) which reflects the cycle number when the fluorescence of reporter dye is higher than background. The threshold, automatically adjusted by instrument, was used for generating $\mathrm{CT}$ values. Real-time PCR efficiencies were determined by amplification of a standardized dilution series, and slopes were obtained. The specificity of desired products was documented using analysis of melting temperature, which is product specific 
and a high resolution gel electrophoresis to confirm that transcripts were of exact molecular size. The mRNA expression of samples with 0 dose treatment was used as calibrator of the corresponding temperature for obtaining relative mRNA expression. The geometric mean of $\mathrm{C}_{t}$ values of the beta actin and RPS15A was used as $\mathrm{C}_{t}$ of reference gene. Efficiency corrected relative quantification of mRNA was obtained by Pfaffl (2001) for which efficiencies of primers were determined by serial dilution of template cDNA sample and running in triplicate.

\section{Immunocytochemistry}

The PBMCs cultured at $37^{\circ} \mathrm{C}$ were centrifuged at $400 \mathrm{xg}$ for $5 \mathrm{~min}$ and the cell pellet was washed and re-suspended with $100 \mu \mathrm{l} 1 \mathrm{xPBS}$. Approximately $1 \times 10^{5}$ cells were spotted onto glass slides pre-treated with polyethylenomine p70@0.3\%. After 5 min when the cells settle down, the fluid was carefully discarded and 50 $\mu 1$ of $3 \%$ PFA in PBS was added, incubated for $15 \mathrm{~min}$ at room temperature. The PFA solution was discarded and the slides were immersed in $100 \%$ methanol in a glass jar at $20{ }^{\circ} \mathrm{C}$ for overnight for fixing. On next day the slides were washed in PBS for $5 \mathrm{~min}$, followed by $0.5 \%$ TritonX-PBS for $15 \mathrm{~min}$ and another wash with PBS for 5 min with a gentle shaking. Just after washing PBMCs were incubated in $50 \mu \mathrm{l}$ blocking solution (3\% bovine serum albumin, BSA in PBS) for 30 min at $37^{\circ} \mathrm{C}$ to block non-specific binding. Thereafter the BSA-PBS was removed and appropriate primary antibodies viz., antiHSP90 (MA1051, Lot \# 08A12) at a 1:200 dilution, anti-HSP70 (MA1050, Lot \# 08A12) at a 1:500 dilution, anti-IL2 (Catalogue no. OAS08776, Lot \#120315) at 1:200 dilution, anti-IL6 (Catalogue no. GTX82951, Lot \#201204) at 1:200 dilutionand 3\% BSA as control were added. After incubation with primary antibody the slides were extensively rinsed 3 times with $0.2 \%$ BSA-PBS for 5-10 min each. After rinsing PBMCs were incubated in a dark humidified chamber at $37^{\circ} \mathrm{C}$ with Cruz Fluor TM (CFL) 488 conjugated secondary antibodies (Goat antirabbit or anti-mouse IgG-CFL 488 and alexa flour 596, 1:1500 dilutions) for $40 \mathrm{~min}$. The primary and secondary antibodies were diluted in $1 \% \mathrm{BSA}$ in PBS. After immune staining, the PBMCs were stained with DAPI $(0.4$ $\mu \mathrm{g} / \mathrm{ml}$ in PBS) to stain the nuclei of the cells over slides. The control was processed under similar conditions except for the omission of the primary antibody. Fluorescently stained cell cultures on glass slides were mounted with anti-fade mounting media (MP Biomedical, France) and images were captured using Axio Observer.Z1 (Carl Zeiss Micro Imaging GmbH, Germany) microscope.

\section{Statistical analyses}

In accordance with the Pfaffl (2001), without treatment sample was used as the calibrator. Data were statistically analyzed by one-way analysis of variance (ANOVA) followed by Duncan's multiple range tests, General Linear Model (GLM) using SAS 9.2 software (SAS Institute Inc., Cary, NC, USA). Mean values were expressed with \pm SEM.

\section{Results and Discussion}

In this study, PBMCs of Indian Black Bengal Goat were utilized as cellular in vitro model to describe and chemical chaperone on expression of HSP's during heat stress. The transcriptional induction of HSP70, HSP90, HSP110, IL2, IL6 and mRNA was used as indicator to evaluate the comparative cellular tolerance ability of PBMCs. Good quality RNA as reflected $\mathrm{A}_{260} / \mathrm{A}_{280}$ ratio of $1.9 \pm 0.22$ was obtained in all the samples types. The melt curve analysis showed single melting peak for each of the analyzed genes indicating quality of qPCR data. Furthermore, high PCR efficiency that ranged from 99.9 to 109.5 was 
observed for different studied genes. In order to normalize the target gene expression data, geometric mean of beta actin and RPS15a was considered as internal control genes. In our study, all the PBMCs that were exposed to the $37^{\circ} \mathrm{C}$ temperature were found to be responsive to in vitro condition. mRNA expression was calculated for HSP70, HSP90 and HSP110, IL2, IL6 taking 0h sample as control (Table 2$6)$.

\section{Expression Kinetics of Heat shock proteins}

The Expression Kinetics of HSP70, HSP90, and HSP110 have been depicted in Figure 1 (A), 1 (B) and 1 (C). eHSP70 at 50ng/ml in cell culture media up-regulated the relative mRNA expression of HSP70, 90 in treatment group at $24 \mathrm{hrs}$ of incubation reaching peak at $4 \mathrm{hrs}(\mathrm{p}<0.05)$, again up-regulated at 20 hours reaching second peak at $24 \mathrm{hrs} \quad(\mathrm{p}<0.05)$ compared to control whereas HSP110 reaching peak at $4 \mathrm{hrs}(\mathrm{p}<0.05)$, and second peak occurred at $20 \mathrm{hrs}$, the level maintained till $24 \mathrm{hrs}$ as compared to control. Immunocytolocalization of HSP70, 90, 110 showed their expression in PBMCs in Figure $2 \mathrm{a}, \mathrm{b}, \mathrm{c}$ respectively.

\section{Expression kinetics of interlukins}

eHSP70 at 50ng/ml in cell culture media upregulated the relative mRNA expression of IL2 (Fig. 1-D) and IL6 (Fig. 1-E) in treatment group reaching peak at $4 \mathrm{hrs}(\mathrm{p}<0.05)$, maintaining the level at $8 \mathrm{hrs}$ and decreases at 12,16 and $20 \mathrm{hrs}$ and again upregulated at 24 hrs reaching second peak $(\mathrm{p}<0.05)$, compared to control. Immunocytolocalization of IL2, 6 showed their expression in PBMCs (Fig. 2d, e).

Stress is the result of environmental forces continuously acting upon animals which disrupt homeostasis resulting in new adaptations that can be detrimental or advantageous to the animal (Stott, 1981). Thermal stress triggers a complex cellular response including altering gene expression (Sonna et al., 2002; Kültz, 2005). It is widely accepted that changes in gene expression are an integral part of the cellular response to thermal stress. Cytokines play a key role in bidirectional communication between the neuro-endocrine and immune system.

HSP70 family of proteins is most temperature sensitive and highly conserved among heat shock proteins. In the present investigation the mRNA expression of HSP70 was found to be significantly higher at higher temperature.

Increased expression of HSP70 mRNA upon exposure to heat stress has been reported in caprine PBMCs (Sharma and Kiran, 2013; Dangi et al., 2014) and bovine lymphocytes (Mishra, 2010; Patirand Upadhyay, 2010; Bharati et al., 2017a). HSP70 play the most dominant role among all the HSP in protecting cells from damage caused by acute thermal stress (Dangi et al., 2014). Our findings are attuned with the findings of Dangi et al., (2012) who reported similar findings of mRNA expression in PBMCs of tropical region Goats.

We obtained higher expression for HSP90 at higher temperature, which is in confirmation with, earlier investigations in Tharparkar cattle PBMCs reporting up regulation of HSP90 expression (Bharati et al., 2017b) during heat stress.

In the present study, the mRNA expressions of HSP70, HSP90, HSP110, IL2 and IL6 were found to be significantly upregulated upon exposure of exogenous HSP70. The transcriptional and translational pattern of HSP70 and HSP90 was upregulated upon exposure to heat stress has been reported in caprine PBMCs and bovine lymphocytes (Mishra, 2010). 
Fig.1 Relative mRNA Expression of heat shock protein and interleukins in PBMC at 0, 1, 2, 4, 8, $12,16,20,24 \mathrm{~h}$ time interval after in vitro cultured with exogenous $\mathrm{HSP} 70$ at $37^{\circ} \mathrm{C}$ (A) Relative mRNA expression of HSP70 (B) Relative mRNA expression of HSP90 (C) Relative mRNA expression of HSP110 (D) Relative mRNA expression IL2 (E) Relative mRNA expression IL6.The data are presented for each individual and as mean \pm SD. The genes were calculated taking zero dose at zero hour (without treatment) as control. * Significant difference from control at $0 \mathrm{~h}(\mathrm{p}<0.05)$
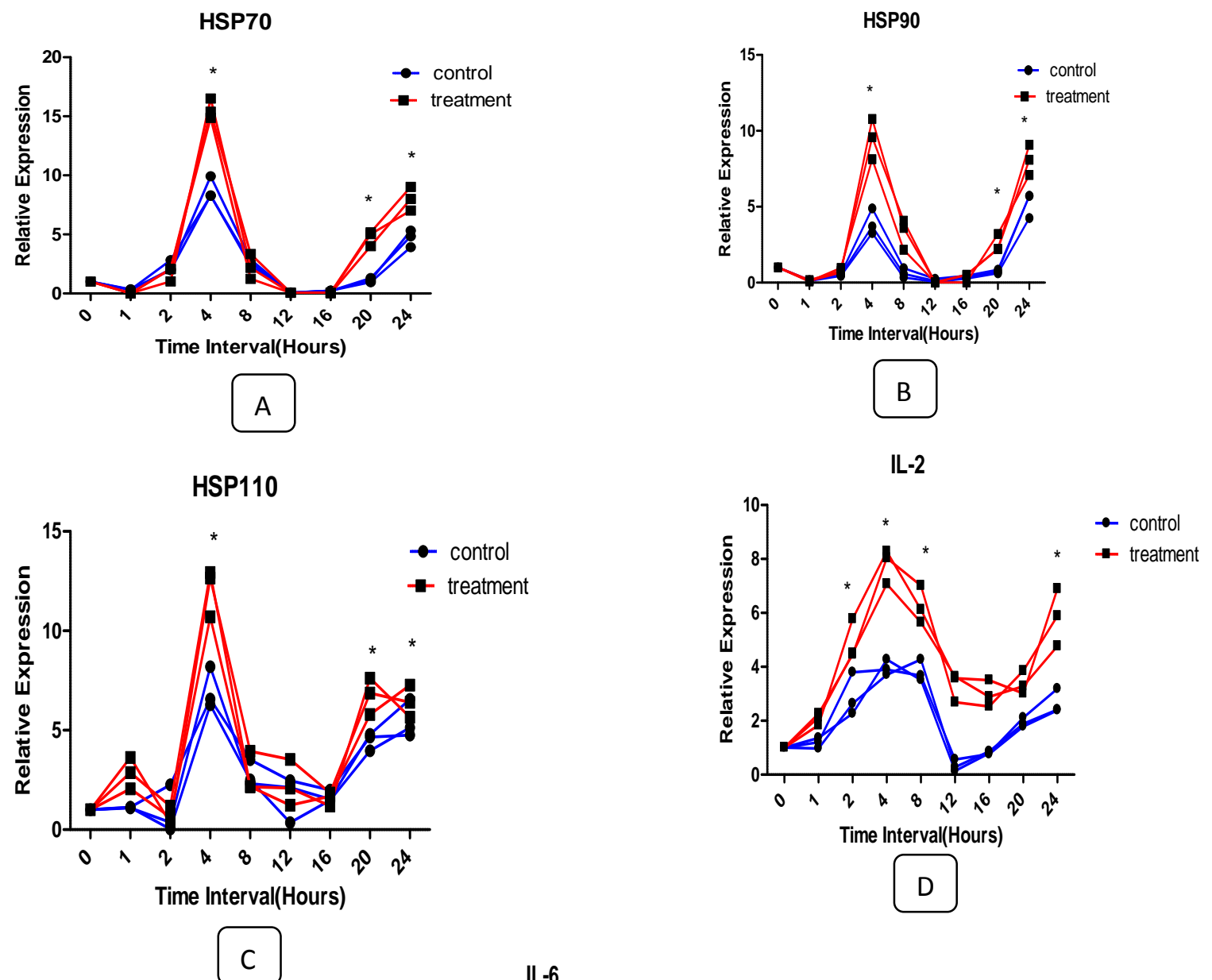

IL-6

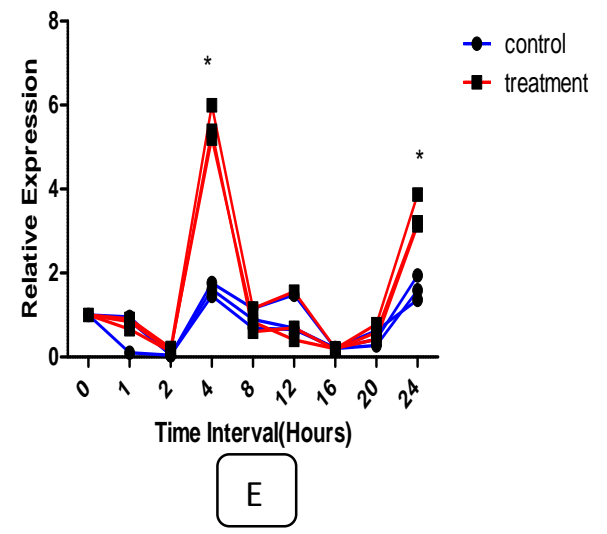


Fig.2 Immunocytochemical localization of (a) HSP70 (b) HSP90 (c) HSP110 (d) IL2 (e) IL6 in PBMCs of Black Bengal Goat. The cultured PBMCs were stained with ALEXA FLUOR 594 and CFL 488 and merged with DAPI counter-stain (blue), indicating the nuclei of all cells in the sections. Negative control sections were presented without primary antibody labelling.

Scale bar $=20 \mu \mathrm{m}$

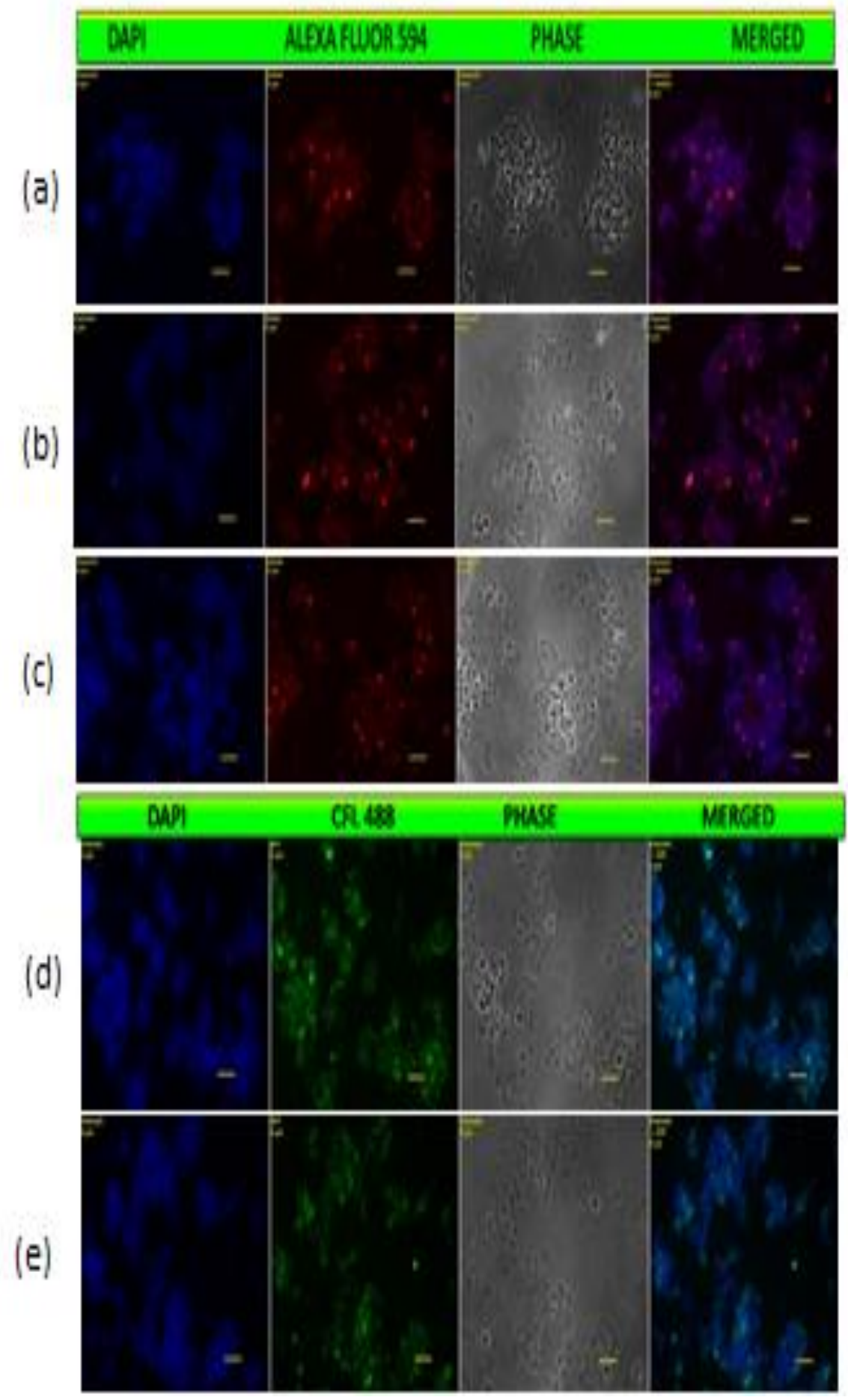


Table.1 Gene transcripts, primer sequence and resulting fragment size

\begin{tabular}{|c|c|c|c|c|}
\hline Gene & Sequence of nucleotide & Fragment size (bp) & Annealing temperature & EMBL/reference \\
\hline HSP 70 & $\begin{array}{l}\text { For: 5'- GACGACGGCATCTTCGAG -3' } \\
\text { Rev: 5'- GTTCTGGCTGATGTCCTTC -3' }\end{array}$ & 132 & $58^{0} \mathrm{C}$ & Dangi et al., (2012) \\
\hline HSP 90 & $\begin{array}{l}\text { For: 5'-GCATTCTCAGTTCATTGGCTATCC- 3' } \\
\text { Rev: 5'-GTCCTTCTTCTCTTCCTCCTCTTC- 3' }\end{array}$ & 190 & $58^{0} \mathrm{C}$ & Dangi et al., (2012) \\
\hline $\begin{array}{l}\text { HSP105/ } \\
110\end{array}$ & $\begin{array}{l}\text { For: 5'-CACAGCCCCAGGTACAAACT - 3' } \\
\text { Rev:: 5'-TCCCTAACTGCCAGACCAAG- 3' }\end{array}$ & 204 & $60^{\circ} \mathrm{C}$ & NM_001075302.1 \\
\hline IL 2 & $\begin{array}{l}\text { For: 5'-ACGGGGAACACAATGAAAGAAG- 3' } \\
\text { Rev: 5'-TGCATCCTGGAGAGCTTGAG- } 3^{\prime}\end{array}$ & 101 & $58^{0} \mathrm{C}$ & AF535145.1 \\
\hline IL6 & $\begin{array}{l}\text { For: 5'-GCTGCTCCTGGTGATGAC- } \text { 3' }^{\prime} \\
\text { Rev: } 5^{\prime} \text { - CGACGATGTGCTTAATGAGAG- } \text { 3' }^{\prime}\end{array}$ & 134 & $60^{\circ} \mathrm{C}$ & D86569.1 \\
\hline RPS $15 a$ & $\begin{array}{l}\text { For: 5'-AATGGTGCGCATGAATGTC- } \text { 3' }^{\prime} \\
\text { Rev: 5'- GACTTTGGAGCACGGCCTAA- 3' }\end{array}$ & 100 & $60^{\circ} \mathrm{C}$ & XM_005679050.1 \\
\hline Beta actin & $\begin{array}{l}\text { For: 5'-AGTTCGCCATGGATGATGA-3' } \\
\text { Rev: 5'-TGCCGGAGCCGTTGT-3' }\end{array}$ & 54 & $60^{\circ} \mathrm{C}$ & Dangi et al., (2012) \\
\hline
\end{tabular}

Table.2 Mean \pm SEM of relative mRNA expression of HSP70 during different time interval on treatment of PBMCswith eHSP70 at $37^{\circ} \mathrm{C}$ in in vitro cell culture system

\begin{tabular}{|c|c|c|c|c|c|c|c|c|c|}
\hline \multirow[t]{2}{*}{ Genes } & \multicolumn{9}{|c|}{ Time interval } \\
\hline & ohr & $1 \mathrm{hr}$ & $2 \mathrm{hr}$ & $4 \mathrm{hr}$ & $8 \mathrm{hr}$ & $12 \mathrm{hr}$ & $16 \mathrm{hr}$ & $20 \mathrm{hr}$ & $24 \mathrm{hr}$ \\
\hline $\begin{array}{l}\text { HSP70 } \\
\text { Control }\end{array}$ & $1 \pm 00$ & $0.32 \pm 0.02$ & $2.88 \pm 0.26$ & $8.83 \pm 0.54$ & $2.60 \pm 0.15$ & $0.07 \pm 0.00$ & $0.23 \pm 0.00$ & $1.13 \pm 0.09$ & $4.62 \pm 0.40$ \\
\hline $\begin{array}{l}\text { HSP70 } \\
\text { Treatment }\end{array}$ & $1 \pm 00$ & $0.01 \pm 0.00$ & $1.72 \pm 0.34$ & $15.58 \pm 0.60$ & $2.25 \pm 0.60$ & $0.06 \pm 0.00$ & $0.04 \pm 0.01$ & $4.73 \pm 0.36$ & $8.01 \pm 0.57$ \\
\hline
\end{tabular}

Table.3 Mean \pm SEM of relative mRNA expression of HSP90 during different time interval on treatment of PBMCs with eHSP70 at $37{ }^{\circ} \mathrm{C}$ in in vitro cell culture system

\begin{tabular}{|l|l|l|l|l|l|l|l|l|l|}
\hline Genes & $\mathbf{9 h r}$ & $\mathbf{1 h r}$ & $\mathbf{2 h r}$ & $\mathbf{4 h r}$ & $\mathbf{8 h r}$ & $\mathbf{1 2 h}$ & $\mathbf{1 6 h r}$ & $\mathbf{2 0 h r}$ & $\mathbf{2 4 h \mathbf { h r }}$ \\
\hline $\begin{array}{l}\text { HSP90 } \\
\text { Control }\end{array}$ & $1 \pm 0.00$ & $0.144 \pm 0.01$ & $0.508 \pm 0.03$ & $3.95 \pm 0.48$ & $0.62 \pm 0.17$ & $0.140 \pm 0.05$ & $0.35 \pm 0.05$ & $0.736 \pm 0.06$ & $5.22 \pm 0.48$ \\
\hline $\begin{array}{l}\text { HSP90 } \\
\text { Treatment }\end{array}$ & $1 \pm 0.00$ & $0.119 \pm 0.2$ & $0.84 \pm 0.08$ & $9.49 \pm 0.76$ & $3.28 \pm 0.57$ & $0.013 \pm 0.00$ & $0.34 \pm 0.16$ & $2.52 \pm 0.32$ & $8.08 \pm 0.57$ \\
\hline
\end{tabular}

Table.4 Mean \pm SEM of relative mRNA expression of HSP110 during different time interval on treatment of PBMCs with eHSP70 at $37{ }^{\circ} \mathrm{C}$ in in vitro cell culture system

\begin{tabular}{|l|l|l|l|l|l|l|l|l|l|} 
Genes & $\mathbf{9 h \mathbf { r }}$ & $\mathbf{1 h r}$ & $\mathbf{2 h r}$ & $\mathbf{4 h r}$ & $\mathbf{8 h r}$ & $\mathbf{1 2 h r}$ & $\mathbf{1 6 h r}$ & $\mathbf{2 0 h r}$ & $\mathbf{2 4 h \mathbf { h r }}$ \\
\hline $\begin{array}{l}\text { HSP110 } \\
\text { Control }\end{array}$ & $1 \pm 0.00$ & $3.44 \pm 0.33$ & $0.88 \pm 0.69$ & $7.01 \pm 0.59$ & $2.77 \pm 0.37$ & $1.64 \pm 0.65$ & $2.00 \pm 0.30$ & $4.46 \pm 0.25$ & $5.48 \pm 0.54$ \\
\hline $\begin{array}{l}\text { HSP110 } \\
\text { Treatment }\end{array}$ & $1 \pm 0.00$ & $9.18 \pm 0.76$ & $0.714 \pm 0.24$ & $12.10 \pm 0.70$ & $2.75 \pm 0.59$ & $2.28 \pm 0.67$ & $1.57 \pm 0.19$ & $6.75 \pm 0.92$ & $6.44 \pm 0.46$ \\
\hline
\end{tabular}

Table.5 Mean \pm SEM of relative mRNA expression of IL2 during different time interval on treatment of PBMCs with eHSP70 at $37{ }^{\circ} \mathrm{C}$ in in vitro cell culture system

\begin{tabular}{|l|l|l|l|l|l|l|l|l|l|} 
Genes & \multicolumn{9}{|c|}{ Time interval } \\
\cline { 2 - 9 } & $\mathbf{0 h r}$ & $\mathbf{1 h r}$ & $\mathbf{2 h r}$ & $\mathbf{4 h r}$ & $\mathbf{8 h r}$ & $\mathbf{1 2 h r}$ & $\mathbf{1 6 h r}$ & $\mathbf{2 0 h r}$ & $\mathbf{2 4 h r}$ \\
\hline $\begin{array}{l}\text { IL-2 } \\
\text { Control }\end{array}$ & $1 \pm 0.00$ & $1.180 \pm 0.11$ & $2.89 \pm 0.45$ & $3.95 \pm 0.16$ & $3.81 \pm 0.22$ & $0.33 \pm 0.12$ & $0.801 \pm 0.02$ & $1.93 \pm 0.09$ & $2.66 \pm 0.26$ \\
\hline $\begin{array}{l}\text { IL-2 } \\
\text { Treatment }\end{array}$ & $1 \pm 0.00$ & $2.07 \pm 0.12$ & $4.91 \pm 0.4$ & $7.79 \pm 0.37$ & $6.25 \pm 0.40$ & $3.30 \pm 0.30$ & $2.97 \pm 0.28$ & $3.38 \pm 0.24$ & $5.85 \pm 0.61$ \\
\hline
\end{tabular}


Table.6 Mean \pm SEM of relative mRNA expression of IL-6 during different time interval on treatment of PBMCs with eHSP70 at $37{ }^{\circ} \mathrm{C}$ in in vitro cell culture system

\begin{tabular}{|c|c|c|c|c|c|c|c|c|c|}
\hline \multirow[t]{2}{*}{ Genes } & \multicolumn{9}{|c|}{ Time interval } \\
\hline & Ohr & $1 \mathrm{hr}$ & $2 \mathrm{hr}$ & $4 \mathrm{hr}$ & $8 \mathrm{hr}$ & $12 \mathrm{hr}$ & $16 \mathrm{hr}$ & $20 \mathrm{hr}$ & $24 \mathrm{hr}$ \\
\hline $\begin{array}{l}\text { IL-6 } \\
\text { Control }\end{array}$ & $1 \pm 0.00$ & $0.64 \pm 0.26$ & $0.04 \pm 0.00$ & $1.61 \pm 0.08$ & $0.91 \pm 0.13$ & $0.94 \pm 0.26$ & $0.26 \pm 0.0$ & $0.44 \pm 0.10$ & $1.63 \pm 0.16$ \\
\hline $\begin{array}{l}\text { IL-6 } \\
\text { Treatment }\end{array}$ & $1 \pm 0.00$ & $0.80 \pm 0.07$ & $0.16 \pm 0.02$ & $5.53 \pm 0.24$ & $0.86 \pm 0.16$ & $0.88 \pm 0.34$ & $0.19 \pm 00$ & $0.59 \pm 0.10$ & $3.40 \pm 0.23$ \\
\hline
\end{tabular}

Thermal stress induces characteristic patterns of circulating cytokines in man and animals that are dominated by acute elevations in various cytokines like IL-6, IL-10 and TNF- $\alpha$ (Bouchama et al., 2005). HSP70 families of proteins are most temperature sensitive and highly conserved among heat shock proteins. TLRs are again the pattern recognition receptor which can recognize microbial markers and or endogenous ligands such as HSP 70 to initiate a complex signalling cascade that activate a wide variety of transcription factors and inflammatory cytokines (Akira and Takeda, 2004). Previous study conducted in baboon shows that heatstroke activates complex, systemic, inflammatory, and regulatory responses characterized by an early and simultaneous release of anti-inflammatory cytokine and soluble cytokine receptors (Bouchama et al., 2005). Through binding to TLR2 and TLR4, recombinant HSP70 can stimulate sentinel cells to release cytokines and increase their antigen-presenting capacity (Vabulas et al., 2002; Gobert et al., 2004). Thus, there may be many possible signalling pathways that could account for stimulation of cytokine production in conditions of heat stress. However, two possible reasons for upregulation of interleukins in regards to HSP may exist. The first arises from the possibilities of HSP70 induced activation of NF-kB and subsequent transcription of cytokines (like IL6) via acting through its membrane receptor. As it has been reported that exogenous HSP70 can activate the production of cytokines via a pathway dependent on CD14 and intracellular calcium influx (Asea et al., 2000). eHSP70 has been shown to activate monocytes, macrophages, and dendritic cells, and up-regulate the expression of pro-inflammatory cytokines (Mortaz et al., 2006). HSP70, in its ability as a chaperone, was involved in antigen acceptance and presentation by macrophages and other followers of the APC group (Suzue and Young, 1996). Furthermore, antigens associated with HSP70 were found to elicit a more pronounced immune response than they did on their own (Barrios et al., 1994). It has been shown that eHSP70 can interact with APCs via a receptor and elicit the release of pro-inflammatory cytokines (Asea et al., 2000; Binder et al., 2000).

Thus, the pattern of cytokine expression in our study may function to suppress subsequent proinflammatory signaling locally or systemically, as the anti-inflammatory effects of IL-6 include suppression of both TNF- $\alpha$ and IL-1 $\beta$ (Starkie et al., 2003). Together, these responses could play critical roles in dampening the proinflammatory pathways, in initiating survival programs and maintaining cell homeostasis during heat stress exposure in Black Bengal Goats.

Persisting stress alters physiological state referred to as acclimation via gene expression in response to endocrine signals or external signals. HSP expression pattern is at least biphasic or two-peak phenomenon. It requires a long term study to further study HSP peak phenomenon consistency. Some genes play important role during initial phase whereas others at later phase to smoothen the 
acclimation process to nullify deleterious effect of thermal stress by maintaining cellular homeostasis. In the acclimated state, metabolism is minimized to counteract the detrimental effects of increased thermal heat load.

\section{Competing Interests}

The authors declare that they have no competing interests.

\section{References}

Akira, S. and Takeda, K. (2004). Toll-like receptor signalling. Nat. Rev. Immunol. 4 (7): 499-511.

Aneja, R., Odoms, K., Dunsmore, K., Shanly, T.P. and Wong, H.R. (2006). Extracellular heat shock protein-70 induces endotoxin tolerance in THP-1 cells. J. Immunol. 177:7184-7192.

Asea, A., Kraeft, S.K., Kurt-Jones, E.A., Stevenson, M.A., Chen, L.B., Finberg, R.W., Koo, G.C. and Calderwood, S.K. (2000). HSP70 stimulates cytokine production through a CD14-dependant pathway, demonstrating its dual role as a chaperone and cytokine. Nat. Med. 6: 435-442.

Barrios, C., Georgopoulos, C. and Lambert, P.H. (1994). Heat shock proteins as carrier molecules: In vivo helper effect mediated by Escherichia coli GroEL and DnaK proteins requires crosslinking with antigen. Clin. Exp. Immunol. 98, 229-233.

Bettaieb, A. and Averill-Bates, D.A. (2008). Thermotolerance induced at a fever temperature of $40 \mathrm{C}$ protects cells against hyperthermia-induced apoptosis mediated by death receptor signalling. Biochem. Cell Biol. 86 (6): 521-538.

Bharati, J., Dangi, S.S., Bag, S., Maurya, V.P., Singh, G., Kumar, P. and Sarkar, M. (2017b). Expression dynamics of
HSP90 and nitric oxide synthase (NOS) isoforms during heat stress acclimation in Tharparkar cattle. Int. J. Biometeorol. 7: $1-9$.

Bharati, J., Dangi, S.S., Chouhan, V.S., Mishra, S.R., Bharti, M.K., Verma, V., Shankar, O., Yadav, V.P., Das, K., Paul, A. and Bag, S. (2017a). Expression dynamics of HSP70 during chronic heat stress in Tharparkar cattle. Int. J. Biometeorol. 61 (6): 1017-1027.

Binder, R.J., Han, D.K. and Srivastava, P.K. (2000). CD91: A receptor for heat shock protein gp 96. Nature Immunol. 1: 151-155.

Blecha, F.and Baker, P.E. (1986). Effect of cortisol in vitro and in vivo on production of bovine interleukin 2.Am. J. Vet. Res. 47 (4): 841-845.

Bouchama, A., Al Mohanna, F., El-Sayed, R., Eldali, A., Saussereau, E., CholletMartin, S. and Roberts, G. (2005). Experimental heatstroke in baboon: analysis of the systemic inflammatory response. Shock, 24 (4): 332-335.

Dangi, S.S., Gupta, M., Maurya, D., Yadav, V.P., Panda, R.P., Singh, G., Mohan, N.H., Bhure, S.K., Das, B.C., Bag, S. and Mahapatra, R. (2012). Expression profile of HSP genes during different seasons in Goats (Capra hircus). Trop. Anim. Health Prod. 44 (8): 1905-1912.

Dangi, S.S., Gupta, M., Nagar, V., Yadav, V.P., Dangi, S.K., Shankar, O., Chouhan, V.S., Kumar, P., Singh, G. and Sarkar, M. (2014). Impact of shortterm heat stress on physiological responses and expression profile of HSPs in Barbari Goats. Int. J. Biometeorol. 58 (10): 2085-2093.

DeJong, P.R.., Schadenberg, A.W.L., Jansen, N.J.G. and Prakken, B.J. (2009). Hsp70 and cardiac surgery: Molecular chaperone and inflammatory regulator with compartmentalized effects. Cell Stress Chaperones. 14: 117-131. 
Doklandy, K., Moseley, P.L. and Ma, T.Y. (2006). Physiologically relevant increase in temperature causes an increase in intestinal epithelial tight junction permeability. Am. J. Physiol. Gastrointest. Liver Physiol. 290: G204G212.

Gobert, A.P., Bambou, J.C., Werts, C., Balloy, V., Chignard, M., Moran, A.P. and Ferrero, R.L. (2004). Helicobacter pylori heat shock protein 60 mediates interleukin-6 production by macrophages via a toll-like receptor (TLR)-2-, TLR-4-, and myeloid differentiation factor 88-independent mechanism. J. Biol. Chem. 279 (1): 245-250.

Han, A.Y, Zhang, M.H., Zuo, X.L., Zheng, S.S., Zhao, C.F., Feng, J.H. and Cheng, C. (2010). Effect of acute heat stress on calcium concentration, proliferation, cell cycle, and interleukin-2 production in splenic lymphocytes from broiler chickens. Poult. Sci. 89 (10): 2063 2070.

Hecker, J.G. and McGarvey, M. (2011). Heat shock proteins as biomarkers for the rapid detection of brain and spinal cord ischemia: A review and comparison to other methods of detection in thoracic aneurysm repair. Cell Stress Chaperones. 16: 119-131.

Hershko, D.D., Robb, B.W., Luo, G.J., Paxton, J.H. and Hasselgren, P.O. (2003). Interleukin-6 induces thermotolerance in cultured $\mathrm{Caco}-2$ cells independent of the heat shock response. Cytokines, 21 (1): 1-9.

Kiang, J.G. (2004). Inducible heat shock protein $70 \mathrm{kD}$ and inducible nitric oxide synthase in hemorrhage/resuscitationinduced injury. Cell Res. 14 (6): 450459.

Kolli, V., Upadhyay, R.C. and Singh, D. (2014). Peripheral blood leukocytes transcriptomic signature highlights the altered metabolic pathways by heat stress in zebu cattle. Res. Vet. Sci. 96 (1): $102-110$.

Kültz, D. (2005). Molecular and evolutionary basis of the cellular stress response. Annu. Rev. Physiol. 67: 225-257.

Mishra, R.P. (2010). Role of housing and management in improving productivity efficiency of Goats. Goat productionprocessing of milk and meat. First edition, page 45.Missouri Agric. Exp. Stat. Res. Bull. No 475.

Mortaz, E., Redegeld, F.A., Kijkamp, F.P., Wong, H.R. and Engels, F. (2006). Acetylsalicylic acid-induced release of HSP70 from mast cells results in cell activation through the TLR pathway. Exp. Hematol. 34: 8-18.

Parikh, A.A., Moon, M.R., Kane, C.D., Salzman, A.L., Fischer, J.E. and Hasselgren, P.O. (1998). Interleukin-6 production in human intestinal epithelial cells increases in association with the heat shock response. J. Surg. Res. 77 (1): 40-44.

Patir, H. and Upadhyay, R.C. (2010). Purification, characterization and expression kinetics of heat shock protein 70 from Bubalus bubalis. Res. Vet. Sci. 88 (2): 258-262.

Pfaffl, M.W. (2001). A new mathematical model for relative quantification in realtime RT-PCR. Nucleic Acids Res. 29: 2002-2007.

Pockley, A.G. (2003). Heat shock proteins as regulators of the immune response. The lancet. 362 (9382): 469-476.

Ruzek, M.C, Miller, A.H., Opal, S.M., Pearce, B.D. and Biron, C.A. (1997). Characterization of early cytokine responses and an interleukin (IL)-6dependent pathway of endogenous glucocorticoid induction during murine cytomegalovirus infection. J. Exp. Med. 185 (7): 1185-1192. 
Sharma, A. and Kiran, R. (2013). Corporate social responsibility: driving forces and challenges. Int. J. Bus. Res. Dev. 2 (1).

Sonna, L.A., Fujita, J., Gaffin, S.L., Lilly, C.M. (2002). Invited review: effects of heat and cold stress on mammalian gene expression. J. Appl. Physiol. 92 (4): 1725-1742.

Starkie, R., Ostrowski, S.R., Jauffred, S., Febbraio, M. and Pedersen, B.K. (2003). Exercise and IL-6 infusion inhibit endotoxin-induced $\mathrm{TNF}-\alpha$ production in humans. FASEB J. 17 (8): 884-886.

Stott, G.H. (1981). What is animal stress and how is it measured? J. Anim. Sci. 52 (1): 150-153.
Suzue, K. and Young, R.A. (1996). Heat shock proteins as immunological carriers and vaccines. EXS. 77: 451465.

Tolnai, S. (1975). A method for viable cell count. Methods Cell Sci. 1 (1): 37-38.

Vabulas, R.M., Wagner, H. and Schild, H. (2002). Heat shock proteins as ligands of toll-like receptors. Curr. Top. Microbiol. zImmunol., 270: 169-184.

Yildirim, N.C. and Yurekli, M. (2010). The effect of adrenomedullin and cold stress on interleukin- 6 levels in some rat tissues. Clin. Exp. Immunol. 161 (1): 171-175.

\section{How to cite this article:}

Tanmay Mondal, Chandrabhan Singh Banjare, Satyaveer Singh Dangi, Sadhan Bag, Mihir Sarkar and Bikash Chandra Das. 2018. The Effect of Exogenous HSP70 on Expression Kinetics of HSP70, HSP90, HSP110 and IL2 and IL6 in Peripheral Blood Mononuclear Cells and Possible Crosstalk between Them in Black Bengal Goat. Int.J.Curr.Microbiol.App.Sci. 7(08): 506-517. doi: https://doi.org/10.20546/ijcmas.2018.708.056 